\title{
Agro-Economic Effeet of Georgian and European BeEkeEping Market
}

\section{Abstract:}

The European Union has expanded a number of times throughout its history by way of the accession of new member countries to the Union. Former USSR republic of Georgia and the EU have maintained relations since 1996. The government expressed a desire to become a member state of the EU. To enhance their relationship, the EU and Georgia have signed several agreement in recent years. EU encourage Georgia to further approximate with European legislation and standards and initiated the process of supporting Georgian economy for further integration into EU. In recent years the European Union has been supporting rural and agricultural development of Georgia, the country with the the longest history of beekeeping and honey production. On 27 June 2014, The European Union and Georgia signed an Association Agreement. The agreement introduced a preferential trade regime - the Deep and Comprehensive Free Trade Area. Based on having better-matched regulations, this regime increases market access between the European Union and Georgia. In this work, alongside with statistics and brief history, we present our view of the future of this cooperation which can be based not only on export of honey to the EU market, but the Georgian Bee itself. It is estimated that pollinators, mainly honey bees, contribute at least 22 billion EUR each year to the European agriculture industry. They ensure pollination for over 80\% of crops and wild plants in Europe. In recent years the quality and area of pollination in Europe has been decreasing. These issues can greatly benefit from the specific characteristics only Georgian Bee is known for, like longest tongue (proboscis) and exceptional gentleness. We strongly believe, that due to various strengths and features only this specie boasts, the export of Georgian Bees will lead to very fruitful collaboration for both parties.

\section{Keywords:}

Agro-Economic effect; Trade; Honey bee; Queen bee; Honey; Beekeeping; EU economy; Pollination; Agriculture; Georgia; Market; ENPARD
Author's data:
${ }^{1}$ Academic doctor of lakob Gogebashvili Telavi State University, Faculty of agrarian scientific, N1, Kartuli Universiteti Str., Telavi, Teee87@gmail.com
2 student of lakob Gogebashvili Telavi state University, Faculty of agrarian scientific, N1, Geoeca@gmail.com
${ }^{3}$ Technical doctor of lakob Gogebashvili Telavi State University, Faculty of agrarian scientific, N1, arina_khositashvili@yahoo.com
${ }^{4}$ Academic doctor of lakob Goqebashvili Telavi State Universitv. Facultv of aararian scientific. N1. Schalatashvili@vahoo.com
International Journal - VALLIS AUREA • Volume 5 • Number 2 • Croatia, December 2019
UDK 338.439(479.22:061.1EU); DOI 10.2507/IJVA.5.2.4.65 


\section{Introduction}

Georgia produces about 4000 tones honey per year. There are five types of honey in large amounts: acacia honey, blossom honey, alpine honey, linden honey and chestnut honey. Most large beekeepers (more than 100 beehives) are engaged in transhumance and harvest honey twice: in late spring (highly depends on the weather) and late summer. Chestnut and linden honey are mainly harvested in Western parts of Georgia [1]. Beside these types, there are specialist honeys in Georgia such as Jara or wild honey, rhododendron honey (known as "mad honey" owing to containing grayanotoxin], honey from laurel, willow, solidago (goldenrod) and others. However, their output is quite low.

\section{Understanding transition}

Through the EU-funded ENPARD Programme Georgia is currently benefiting from EUR 52 million in support for agricultural and rural development. Launched in 2012, the Programme aims to reduce rural poverty and boost the production of food in Georgia. On 27 June 2014 The EU and Georgia signed an Association Agreement, which entered into force on 1 July 2016. The agreement introduced a preferential trade regime - the Deep and Comprehensive Free Trade Area (DCFTA). Based on having better-matched regulations this regime increases market access between the $\mathrm{EU}$ and Georgia.

In 2017 Georgian honev entered European market. According to European Commission report - EU Honey production is about $200000 \mathrm{t}$. Honey imported into the EU equals to 165500 t.
Data processing: Launched in 2012, the program aims to reduce rural poverty and boost the production of food in Georgia. Which positively reflected on the number of scales and dynamics of product growth. In the diagram 1 and 2 is presented numbers of beehives in Georgia (ths, beehives) by ENPARD, Implementing partner : Association of Young Economists of Georgia.

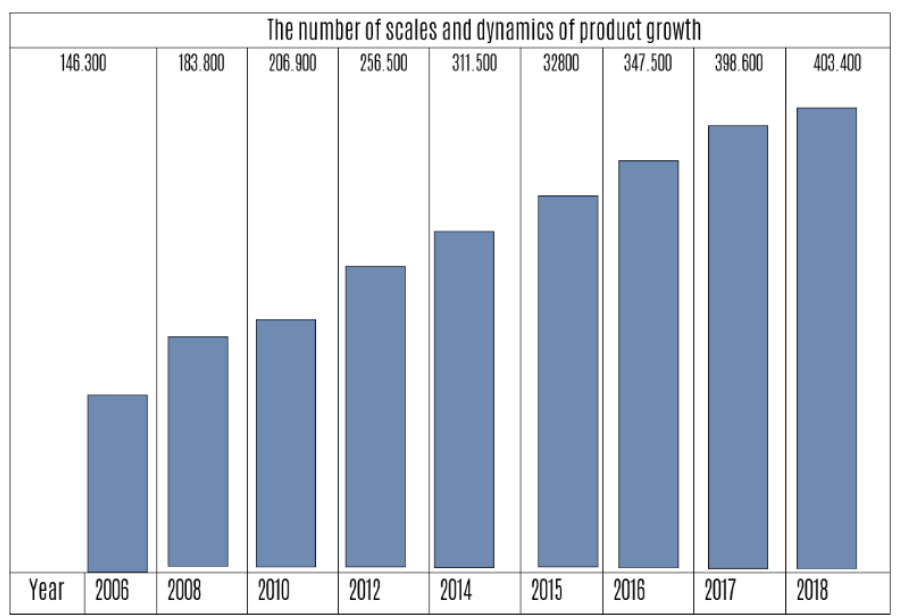

Figure 1. Numbers of beehives in Georgia (ths. beehives) DY ENPARD

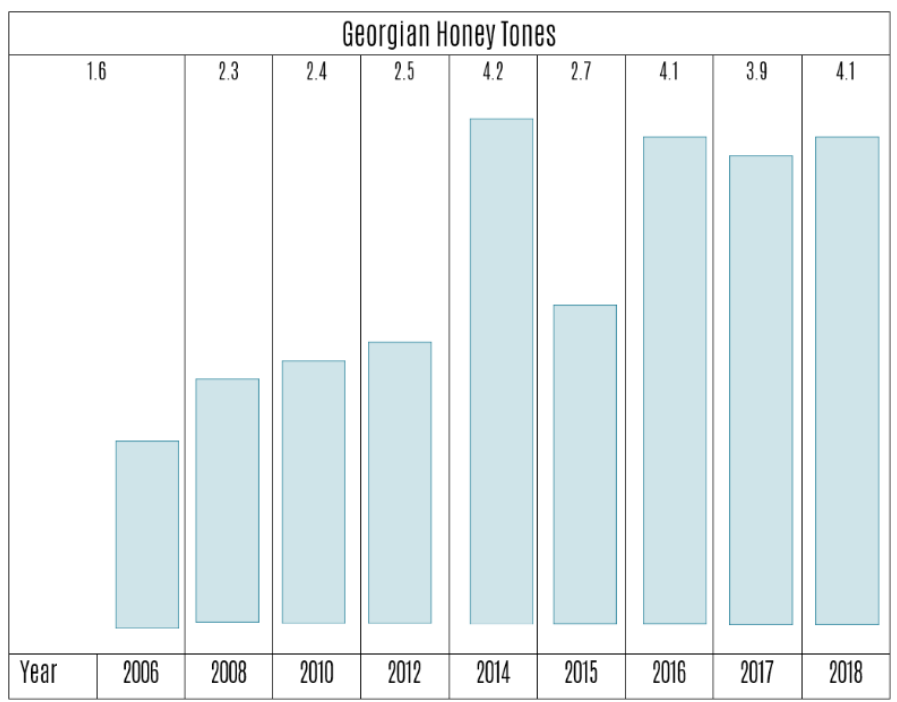

Figure 2. Honey production in Georgia (ths. tones).

Caucasian flora - Georgian flora is extremely diverse and rich. It is very interesting from the ecological point of view. Located between the 
forests of northern Eurasia and the tropical deserts of Iraq and Iran, incorporating Europe's highest mountains and a subtropical coastline, it has a high level of biodiversity. Conservation International recently designated Georgia as one of its 25 global "biodiversity hotspots" because of the area's exceptional number of endemic species (those found nowhere else). Endemic species comprise about $9 \%$ of Georgia 's flora, a surprisingly high proportion for so small country [4].

There are about 5,000 species of vascular plants lof which 380 are endemic to Georgia and about 600 to the Caucasus], and about 8,400 - 10,000 cryptogamous or spore-bearing plants. High Caucasus is also rich in endemics; thickdeciduous forest is spread on the lower to mid-altitude of the southwestern slopes and is described as 'temperate rainforest'.

There's a wide variety of plant communities, with examples of almost all the main habitat types found in Europe and some of those in Asia; many are highly valuable in terms of biodiversity, including sub-alpine coniferous forests, meadows, wetlands, peat bogs and lakes; coniferous and beech forests; oak woodlands; caves and mountain gorges; unique colchic forests with evergreen undergrowth; Mediterranean and sub-Mediterranean communities; steppe grasslands; arid light woodlands; as well as riparian shrub and forest vegetation along rivers [3].

The Caucasus district lies in the north at 2,000m and higher, with a severe climate and annual precipitation over a meter. It harbours some of the most diverse and distinctive temperate coniferous and deciduous forests in Eurasia, ranging with altitude from sub-alpine beech woods, dark coniferous forests and crook-stem woods to subalpine, alpine and subnival plant communities and, above these, bare nival landscapes.

Georgian honey is harvested in ecologically clean and non polluted areas and it will offer EU market good quality \& different types of honey [9].

Georgian beekeeping share to EU based on honey export is low, however, it might be very significant in case of Queen bee export.

Modern beekeeping is mainly focused in smart technologies and its integration with hive for better management. This is a promising approach, which needs further development in order to help achieve much needed results. However, the problem is not only in technology. Beekeeping in EU faces different problems such as pollution, various infections and parasites like Varroa destructor and small hive beetle. In addition, Colony collapse Disorder (CCD) poses a great danger for beekeeping recovery in many countries. These cause enormous problems to EU environment and economy, as bees are critically important [2]. It is estimated that pollinators, mainly honey bees, contribute at least 22 billion EUR each year to the European agriculture industry. They ensure pollination for over $80 \%$ of crops and wild plants in Europe. Honey bees also provide honey and other apiculture products such as pollen, wax for food processing, propolis in food technology, and royal jelly used as a dietary supplement and as an ingredient in food[6].

EU will greatly benefit from other beekeeping product imported from Georgia, namely queen bees, which will significantly increase the share of Georgia in overall EU economy.

Caucasian grey mountain honeybee (Apis mellifera caucasia] - Georgia has a long history of 
beekeeping. So far, the oldest remains of honey have been found in Georgia. Archaeologists have found honey remains on the inner surface of clay vessels of an unearthed ancient tomb during BakuTbilisi-Ceyhan oil pipeline construction, dating back to some 5,500 years ago [8].

\section{Market characteristics}

\section{Caucasian bees are:}

- $\quad$ The most gentle bees in the world

- Winder-hardy

- $\quad$ Productive

- $\quad$ Agile, with ability to fly in cool

temperatures and even in light rain, that other races of bees will not even dare.

- $\quad$ Longest tongue $(7,1 \mathrm{~mm}-7,3 \mathrm{~mm})$, therefore can reach nectar that its competitors cannot. Worldwide popularization

Famous American entomologist, researcher and beekeeping innovator Frank Benton (1852-1919) greatly supported the popularization and the import of Georgian honeybees to the Europe and United States. In modern times, 3 gold medal awards started a new era of popularization of Georgian grey honeybees. First Gold Medal was given to the Georgian honeybee in 1961, at the International Exhibition of Gardening in Erfurt [Germany], next time, the Georgian honeybee was awarded a Gold Medal at the jubilee celebration of the APIMONDIA 20th International Congress of Agriculture in Bucharest (Romania) in 1965, and the third Gold Medal was received at the jubilee celebration of the APIMONDIA 23th International Congress of Agriculture in Moscow in 1971 [10].

\section{Referring}

According to Sunday Mirror, a newspaper published in UK: "GOLDEN BEE the grey mountain bee of the Soviet Union has been judged the best in the world and awarded a gold medal. The grey caucasian bee is distinguished for its industry and it collects honey, even when it is raining. Many foreign beemasters have requested for the Golden bee and as many as 200000 have been sent to Europe, Asia and America this year." (Sunday Mirror June, 11969)

International Awards of Georgia Honey
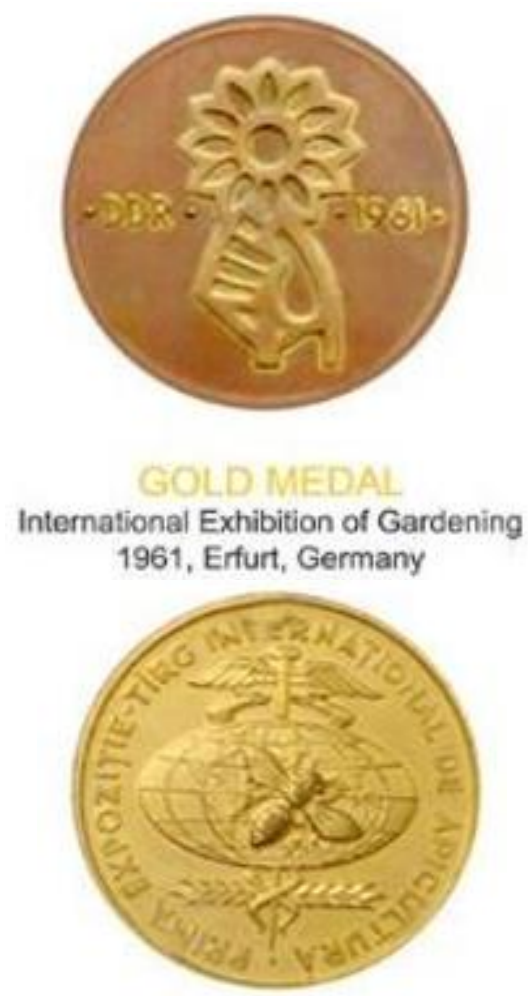

APIMONDIA 20th International

Congress of Agriculture 1965 , Bucharest, Romania 


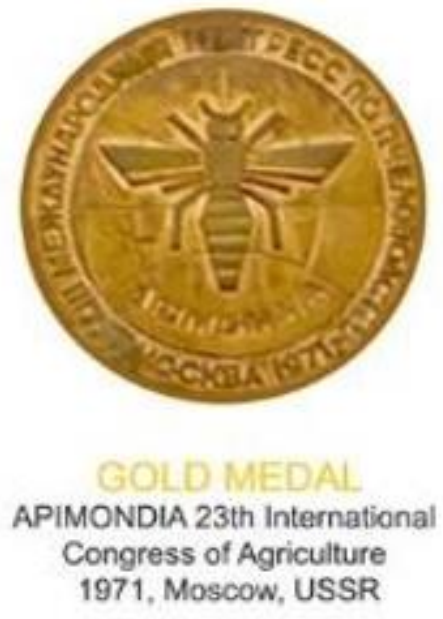

Picture 1. International Awards Of Georgia Honey

According to Georgian beekeeping company GOLDBEE, there is an increased demand for Caucasian queen bees in recent years. To support US declining bee population, US entomologist Walter S. Sheppard [Washington State University] has started taking bee semen from Georgia [5].

\section{Conclusion}

The grey Caucasus mountain honeybee (Apis mellifera caucasia], one of the world's three types of honeybees, has a legendary ability to produce large amounts of honey despite adverse conditions. They can fly in cold weather, even in light rain. For thousands of years this species were native to Georgia, Caucasus.

Georgian bee's abilities will greatly benefit pollination issues in EU. Thanks to its longest tongue (proboscis] it will pollinate more plants than any other bee. This will increase the quality and area of pollination in EU.

Many cities allowed urban beekeeping in recent years, Georgian bees are probably the best choice for urban beekeepers as they are the most gentle ones. The other important factor is that, thanks to their longest proboscis, Georgian bees are able to collect nectar from wide variety of plants.

According to different statistics, women and youth rarely participate in modern beekeeping. Smart and gentle Georgian bees will make it easier for beginners to take up beekeeping. With all the mentioned characteristics, the Caucasian bees are probably the best bees for restoration of bee colonies worldwide and Georgian queen bees are believed to be one of the most promising export products.

Georgian government, the Ministry of Agriculture and beekeeping companies are ready to participate in the Programs to support the restoration of honeybee population in the EU, as well as to collaborate with research centers and universities. Georgia meets all the EU requirements and there are 10 active laboratories in the country, which perform all the basic analysis \& certification ALCP. The last step in the process is a legislation issue, which will allow the legal export of Georgian bees to the EU market.

\section{References}

[1] EU Commision Fast facts :

https://ec.europa.eu/food/sites/food/files/anim als/docs/la_bees_infograph_bee-

health_201507.pdf Accessed: 20.09.2019.

[2] WWF hotspots https://wwf.panda.org/

Accessed: 20.09.2019.

[3] Frank Benton

https://en.wikipedia.org/wiki/Frank_Benton

Accessed: 15.08 .2019$.

[4] National Geographic's

http://www.nationalgeographic.ge/wm.php?page 
=magazine2\&amp;id=620\&amp;fotocat=554

Accessed: 19.09 .2019$.

[5]Eurasianet: Georgia Offers a super Bee to Help

Ailing American Bees

https://eurasianet.org/georgia-offers-a-super-

bee-to-help-ailing-american-bees Accessed:

19.09.2019.

[6] Alliances Caucasus Programme

http://alcp.ge/ Accessed: 19.09.2019.

[7] GOLDBEE https://goldenbee.ge/ Accessed:

01.09 .2019 .

[8] European Commission - Honey bees

https://ec.europa.eu/food/animals/live_animals

/bees_en Accessed: 01.09.2019.

[9] Status of breeding practices and genetic

diversity in domestic U.S. honey

beeshttps://www.researchgate.net/publication/3

03873161_Status_of_breeding_practices_and_gene

tic_diversity_in_domestic_US_honey_bees

Accessed: 01.09.2019.

[10] Michigan State University Archives and

Historical Collections

http://archives.msu.edu/findaid/062.html

Accessed: 03.09 .2019$. 